\title{
Biotransformation of Tributyltin chloride by Pseudomonas stutzeri strain DN2
}

\author{
Dnyanada S. Khanolkar, Milind Mohan Naik, Santosh Kumar Dubey \\ Laboratory of Bacterial Genetics and Environmental Biotechnology, Department of Microbiology, \\ Goa University, Goa, India.
}

Submitted: July 24, 2013; Approved: April 17, 2014.

\begin{abstract}
A bacterial isolate capable of utilizing tributyltin chloride (TBTCl) as sole carbon source was isolated from estuarine sediments of west coast of India and identified as Pseudomonas stutzeri based on biochemical tests and Fatty acid methyl ester (FAME) analysis. This isolate was designated as strain DN2. Although this bacterial isolate could resist up to $3 \mathrm{mM}$ TBTCl level, it showed maximum growth at $2 \mathrm{mM}$ TBTCl in mineral salt medium (MSM). Pseudomonas stutzeri DN2 exposed to $2 \mathrm{mM}$ TBTCl revealed significant alteration in cell morphology as elongation and shrinkage in cell size along with roughness of cell surface. FTIR and NMR analysis of TBTCl degradation product extracted using chloroform and purified using column chromatography clearly revealed biotransformation of TBTCl into Dibutyltin dichloride $\left(\mathrm{DBTCl}_{2}\right)$ through debutylation process. Therefore, Pseudomonas stutzeri strain DN2 may be used as a potential bacterial strain for bioremediation of TBTCl contaminated aquatic environmental sites.
\end{abstract}

Key words: $\mathrm{TBTCl}$, morphological alteration, biotransformation, $\mathrm{DBTCl}_{2}$, bioremediation.

\section{Introduction}

Organotin compounds including TBTCl have been extensively employed in a variety of industrial products such as antifouling paints for boats, wood preservatives, biocides and plastic stabilizers (Gadd, 2000). A great deal of research has indicated that among the organotin compounds, TBTCl is the most toxic compound known to aquatic ecosystems (Gadd, 2000; Dubey and Roy, 2003). The biocidal properties of organotin compounds also make TBTCl an ecological threat to non target organisms exposed to it in aquatic ecosystems (Horiguchi 2006; Sousa et al., 2010; Lemos et al., 2011). It is found to be extremely hazardous to some aquatic organisms as it can induce imposex in female mollusks and can cause thickening of shells in oysters by being toxic even at $\mathrm{nM}$ concentrations in water (Bryan et al., 1988; Horiguchi, 2006; Sousa et al., 2010; Lemos et al., 2011). TBTCl has also been identified as immune system inhibitor and endocrine disruptor in humans (Bryan et al., 1988; Dubey and Roy, 2003; Horiguchi, 2006; Sousa et al., 2010; Lemos et al., 2011). In the aquatic environment, TBTCl is quickly removed from the water column and adheres to sediments as it has high specific gravity (i.e. 1.2). Its low water solubility (less than $10 \mathrm{mg} / \mathrm{L}$ at $20^{\circ} \mathrm{C}$ and $\mathrm{pH} 7$ ) is also responsible for its strong binding to suspended particulate organic and inorganic materials in the aquatic sediment. The degradation rate of TBTCl is observed to be significantly slower within sediments than in the water columns. Earlier studies have revealed that half life of $\mathrm{TBTCl}$ in marine sediments ranges from 0.91 to 5.2 years (Clark et al., 1988; Dowson et al., 1996; Ayanda et al., 2012). TBTCl is known to be highly toxic to both prokaryotes and eukaryotes, while the mono-, di- and tetra-organotins are almost non toxic or barely toxic and seem to exert toxicity through their interaction with membrane lipids (Cruz et al., 2010). The total butyltins in water samples vary between $\sim 12$ and $73 \mathrm{ng} \mathrm{Sn} \mathrm{L}^{-1}$ and from 0.5 to $77 \mathrm{ng} \mathrm{Sn} \mathrm{L}^{-1}$; whereas, in sediments it ranges from 15 to 118 and 6 to $119 \mathrm{ng} \mathrm{Sn} \mathrm{g}^{-1}$ of sediment for the Mandovi and the Zuari estuaries, respectively (Garg et al., 2010).

In nature transformation of TBTCl into less toxic compounds $\left(\mathrm{DBTCl}_{2}\right.$ and $\mathrm{MBTCl}_{3}$ ) by abiotic mechanisms such as chemical cleavage, thermal cleavage and UV irradiation has been reported (Clark et al., 1988; Dowson et al., 
1996; Ayanda et al., 2012). Although TBTCl is highly toxic to majority of microbes some natural microbial strains employing a variety of protective biochemical and molecular genetic mechanisms can survive at very high concentrations of TBTCl without any impact on their growth and metabolism (Pain and Cooney, 1998; Dubey et al., 2006; Cruz et al., 2007, 2010; Krishnamurthy et al., 2007; Ramachandran and Dubey, 2009; Fukushima et al., 2009, 2012; Sampath et al., 2012; Shamim et al., 2012). Several mechanisms involved in TBTCl resistance in bacteria include (i) exclusion of the compound from the cell mediated by multidrug efflux pump (Jude et al., 2004); (ii) degradation/ metabolic utilization as a carbon source (Kawai et al., 1998); (iii) bioaccumulation into the cell without breakdown of the compound (Fukagawa et al., 1994); (iv) unique morphological alteration in the form of long interconnected chains of bacterial cells on exposure to TBTCl (Shamim et al., 2012). This unique characteristic of TBTCl resistant microbes including bacteria makes them an ideal biological tool for bioremediation of TBTCl contaminated sites and thus facilitate restoration of polluted environment.

Biotransformation of TBTCl by bacteria, algae and fungi does occur and is believed to proceed by successive debutylation reactions from $\mathrm{TBTCl} \rightarrow \mathrm{DBTCl}_{2} \rightarrow \mathrm{MBTCl}_{3}$ $\rightarrow$ inorganic tin via $\beta$-hydroxylation with appropriate dioxygenases (Clark et al., 1988; Dowson et al., 1996; Ayanda et al., 2012). As microbial degradation is observed as a predominant biological process for breakdown of TBTCl in coastal waters (Dubey and Roy, 2003; Suehiro et al., 2006; Ayanda et al., 2012), it is imperative and interesting to investigate the transformation of $\mathrm{TBTCl}$ mediated by bacteria thriving in such econiches.

In the present communication, we have reported isolation and identification of TBTCl biotransforming marine bacterial isolate, obtained from coastal sediments of west coast of India (Goa) along with analytical characterization of degradation product of TBTCl and morphological characterization of bacteria strain exposed to TBTCl.

\section{Materials and Methods}

\section{Isolation and Identification of TBTCl resistant bacterial strain}

A bacterial strain DN2 was isolated from coastal sediments of the Zuari estuary, Goa. Serially diluted coastal sediment sample was spread plated on mineral salt medium (MSM) agar supplemented with $0.2 \mathrm{mM} \mathrm{TBTCl}$ as a sole source of carbon and plates were incubated at room temperature for a $24 \mathrm{~h}$ to 1 week. The isolated bacterial colonies which appear were selected as TBTCl resistant and further spot inoculated on MSM agar plates supplemented with different levels of TBTCl $(0.5 \mathrm{mM}-5 \mathrm{mM})$. The bacterial colony which grew at highest $\mathrm{TBTCl}$ concentration was selected for further characterization and designated as strain DN2. The composition of MSM (1 L) used for growth and biotransformation experiment consisted of ferrous sulfate
(0.06 g), dipotassium hydrogen orthophosphate (12.6 g), potassium dihydrogen orthophosphate $(3.64 \mathrm{~g})$, ammonium nitrate $(2 \mathrm{~g})$, magnesium sulfate $(0.2 \mathrm{~g})$, manganese sulfate $(0.0012 \mathrm{~g})$, sodium molybdate $(0.0012 \mathrm{~g})$ and dehydrated calcium chloride (0.15 g) (Sigma Aldrich, USA). The isolate was maintained on MSM containing $2 \mathrm{mM} \mathrm{TBTCl,} \mathrm{pH}$ 7.4 and stored at $4{ }^{\circ} \mathrm{C}$. It was tentatively identified using Gram staining, morphological and biochemical characteristics following Bergey's Manual of Systematic Bacteriology (Krieg and Holt, 1984), and fatty acid methyl ester (FAME) analysis (Sherlock version 6.0B).

\section{Fatty acid methyl ester (FAME) analysis}

Bacterial isolates were grown on trypticase soy agar (TSA) at their optimum growth conditions. Whole cell fatty acids were extracted from cell material and derivatised to Fatty acid methyl esters according to the MIDI protocol (Sasser, 1990). Gas chromatographic analysis of fatty acid methyl esters was performed on a GC Sherlock microbial identification system (New York, USA) fitted with crosslinked methyl silicon fused capillary column $(25 \mathrm{~m}, 0.2 \mathrm{~mm}$ i.d.), flame ionization detector (FID) and a sampler. Helium was used as carrier gas. The sample was injected at oven temperature of $50{ }^{\circ} \mathrm{C}$. After $1 \mathrm{~min}$, the oven temperature was raised to $170{ }^{\circ} \mathrm{C}$ at the rate of $30{ }^{\circ} \mathrm{C} / \mathrm{min}$ and then to $270{ }^{\circ} \mathrm{C}$ at the rate of $2{ }^{\circ} \mathrm{C} / \mathrm{min}$ and finally to $300{ }^{\circ} \mathrm{C}$ at $5^{\circ} \mathrm{C} / \mathrm{min}$. FAME profile of our sample was compared with standard FAME profile of MIDI Sherlock version 6.0B.

\section{Study of growth behaviour and TBTCI resistance} limit

Growth behaviour and TBTCl (Sigma Aldrich, USA) resistance limit of the selected bacterial isolate was studied in Mineral salt medium supplemented with varying concentrations of $\operatorname{TBTCl}(0.5,1,2,3$, and $4 \mathrm{mM})$ as a sole carbon source to find out the optimum concentration of TBTCl for cell growth at $28{ }^{\circ} \mathrm{C}$, pH 7.4 with constant shaking at $150 \mathrm{rpm}$ in an Erlenmeyer flask. As a negative control MSM was inoculated with the bacterial strain without any carbon source. Absorbance of the culture suspension was recorded at definite time intervals of $6 \mathrm{hrs}$ at OD $600 \mathrm{~nm}$ using UV-Vis spectrophotometer (Shimadzu, UV-2450, Japan) and graph was plotted between absorbance and time interval. Growth of the isolated was also recorded as cell dry weight in terms of $\mathrm{g} / \mathrm{L}$.

\section{Scanning electron microscopy}

In order to reveal morphological alterations in presence of TBTCl, scanning electron microscopic (SEM) analysis (JEOL JSM-5800LV, Japan) was performed using the bacterial strain grown in MSM supplemented with $2 \mathrm{mM}$ TBTCl. Bacterial strain grown in MSM with $0.1 \%$ glucose as sole carbon source was taken as control. Culture smear was prepared on a glass slide, air dried and then fixed in 3\% glutaraldehyde overnight with $50 \mathrm{mM}$ potassium phosphate 
buffer. The glass slide was then washed thrice with phosphate buffer and dehydrated in gradually increasing concentrations of ethanol, i.e., 10, 20, 50, 70, 80, 90, 95, and $100 \%$ for $15 \mathrm{~min}$ each. The glass slide was subsequently air dried and stored in vacuum chamber prior to SEM analysis (Naik and Dubey, 2011).

\section{Biotransformation studies}

\section{Extraction and thin layer chromatographic (TLC) analysis} of biotransformation product

Bacterial strain DN2 was grown in $250 \mathrm{~mL}$ Erlenmeyer flask containing $100 \mathrm{~mL}$ MSM (starting inoculum size; OD of 0.025 which is equivalent to $0.007 \mathrm{gm} / \mathrm{L}$ ) with $2 \mathrm{mM} \mathrm{TBTCl}$ as a sole source of carbon at $28^{\circ} \mathrm{C}$ in an incubator shaker at $150 \mathrm{rpm}$ for 1 week. Similarly, an uninoculated flask containing MSM (100 mL) with $2 \mathrm{mM}$ TBTCl was used as a control. After incubation the cell pellet was harvested by centrifugation at $8000 \mathrm{rpm}$ and the cell free supernatant was separated. The cell free supernatant was extracted using double volume of distilled chloroform. The organic layer was collected in a conical flask. The chloroform extract was reduced under vacuum and the concentrated sample was then loaded on a pre activated TLC plate and developed using the solvent system, petroleum ether: acetic acid (9.5:0.5). The TLC plate was subsequently exposed to iodine vapours to develop the spot. The location of the spot was marked and scraped off from the TLC plates. The product was extracted by repeated washing of silica gel with chloroform. The concentrated and residual extract was further purified by silica gel H-20 column chromatography (SIGMA, $30 \times 2 \mathrm{~cm}$ glass column). Slurry of silica gel H-20 was prepared by mixing $9 \mathrm{gm}$ of silica in $20 \mathrm{~mL}$ of ether $\left(40-60^{\circ} \mathrm{C}\right)$. A glass column $(15.5 \mathrm{~cm})$ was packed by adding the slurry with the help of a glass rod and gently tapped to avoid any void volume. The concentrated residual extract was added to the column and chloroform was passed through the column. Purity of eluted product was checked by TLC. The same procedure was repeated for the control flask.

\section{FTIR and UV-Vis Spectrophotometric analysis of purified biotransformation product}

The eluent obtained after purification by column chromatography was further concentrated under vacuum, dried and weighed using electronic weighing machine. The purified product was stored in a glass screw capped vial at $4{ }^{\circ} \mathrm{C}$ until use. The purified biotransformation product was analyzed in the region 400-4,000 $\mathrm{cm}^{-1}$ using (SHIMADZU-FTIR 8201 PC instrument, Japan) in order to find out different transformation products of TBTCl. The purified product was also analyzed spectrophotometrically using UV-Vis Spectrophotometer (Shimadzu UV-2450, Japan) at $236 \mathrm{~nm}$.

\section{NMR analysis of purified biotransformation product}

Nuclear magnetic resonance spectrum analysis $\left(\mathrm{H}^{1}\right.$ NMR) of the control product and purified biotransformation product were recorded with the help of an NMR spectrometer (BRUKER WT, $300 \mathrm{MHz}$ ) in deuterated chloroform $\left(\mathrm{CDCl}_{3}\right)$ with tetramethyl silane (TMS) as an internal standard. Sample $(5 \mathrm{mg})$ to be analysed was dissolved in deuterated $\mathrm{CDCl}_{3}(0.6 \mathrm{~mL})$ and placed in an NMR tube ( $5 \mathrm{~mm}$ diameter). The NMR tube was then appropriately positioned in a spinner and introduced into the NMR spectrometer. All the reagents were purchased from Sigma Aldrich, USA. (Devi et al., 2010).

\section{Results and Discussion}

\section{Identification of TBTCI resistant bacterial strain}

The TBTCl resistant bacterial strain DN2 was isolated from coastal sediments of the Zuari estuary, Goa, India since it is reported to be highly contaminated with TBTCl (> 1.3 ng Sn/g) (Jadhav et al., 2009). These TBTCl contaminated estuarine sediments are responsible for natural enrichment of TBTCl resistant microbes including bacteria. The bacterial strain DN2 was Gram negative, motile, rod shaped, and oxidative. It also showed presence of enzymes viz. oxidase, catalase and gelatinase. Indole, methyl red and Voges Proskaeur's tests were found negative but it utilized citrate. Bacterial strain DN2 didn't produce any pigment. Based on biochemical and morphological characteristics strain DN2 was identified as Pseudomonas stutzeri and further confirmed by FAME analysis.

\section{Growth behaviour and TBTCI resistance limit}

Pseudomonas stutzeri strain DN2 evidently showed an initial lag of $6 \mathrm{~h}$, followed by a long exponential phase in presence of $0.5,1$ and $2 \mathrm{mM}$ TBTCl respectively, whereas $3 \mathrm{mM}$ TBTCl induced an extended lag of $24 \mathrm{hr}$. It showed best growth in presence of $2 \mathrm{mM}$ TBTCl among the tested concentrations whereas it could resist TBTCl up to $3 \mathrm{mM}$ while $4 \mathrm{mM}$ level of this biocide proved lethal due to cytotoxic effects. (Figure 1). Pseudomonas stutzeri strain DN2 didn't show any growth in MSM without TBTCl (Figure1). There are very few reports on TBTCl resistant estuarine bacteria which include TBTCl resistant estuarine Aeromonas caviae strain KS-1 from Mandovi estuary, Goa, India which tolerates TBTCl up to $1.0 \mathrm{mM}$ (Shamim et al., 2012). Aeromonas veronii, a tributyltin (TBT) degrading bacterium isolated from an estuarine environment of Ria de Aveiro in Portugal can tolerate TBT up to $3 \mathrm{mM}$ in nutrient rich Trypticase Soy Broth medium (Cruz et al., 2007). Tributyltin chloride degrading Pseudomonas spp. capable of growth in MSM containing $2 \mathrm{mM} \mathrm{TBTCl}$ as a sole source of carbon, have also been isolated earlier from Indian coastal waters (Sampath et al., 2012). Suehiro et al., (2006) reported degradation of tributyltin in microcosm using Mekong river sediments. Tributyltin resistant estuarine 


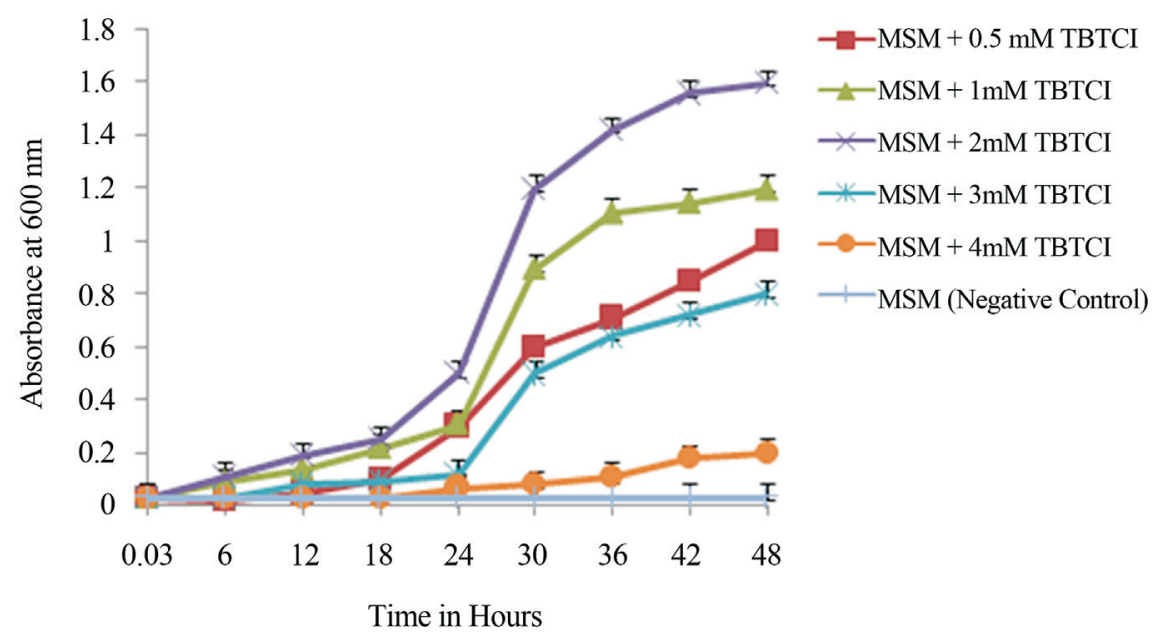

Figure 1 - Growth behaviour of Pseudomonas stutzeri strain DN2 in MSM amended with different concentrations of tributyltin chloride as a sole carbon source. Bacteria inoculated in plain MSM without TBTCl is considered as negative control.

bacterial isolates capable of growing on $8.4 \mu \mathrm{M}$ TBT were isolated from Boston Harbor which belonged to Pseudomonas spp. and Enterobacteriaceae family (Wuertz et al., 1991). Shewanella putrefaciens also showed growth in sea water medium supplemented with low levels of tributyltin (Lee et al., 2012). But till date TBTCl biotransformation product generated by resistant estuarine bacteria has not been analysed yet.

Pseudomonas stutzeri strain DN2 was identified as a potent TBTCl degrader as it could grow best in MSM with $2 \mathrm{mM}$ TBTCl among the tested concentrations as a sole carbon source. It has been reported that oraganotin compounds are toxic to both gram positive as well as gram negative bacteria isolated from sediments; nevertheless, the former showed increased sensitivity to organotins while gram negative bacteria were found to be more resistant to this biocide (Mendo et al., 2003).

\section{Scanning electron microscopy}

Scanning Electron Microscopy of Pseudomonas stutzeri strain DN2 cells exposed to $2 \mathrm{mM}$ TBTCl clearly demonstrated significant morphological alterations as cell elongation, wrinkling and shrinkage (supplementary Figure 1). While cells grown in absence of TBTCl showed a normal morphology and cells inoculated in plane MSM didn't show growth. Alterations in cell morphology as cell elongation, wrinkling and shrinkage leads to possible decrease in the surface area of the cells thereby resulting in reduced adsorption capacity of the cells to TBTCl. Similar findings have suggested that bacterial cells grown in presence of TBTCl were smaller than normal size and appeared aggregated (Cruz et al., 2007). Our earlier studies have also demonstrated that Aeromonas caviae strain KS-1 under the stress of TBTCl protects itself by forming long chains of cells which reduces the surface to volume ratio and results in reducing the exposed cell surface for TBTCl (Shamim et al., 2012). It has also been demonstrated that certain components on the cell surface of $\mathrm{TBTCl}$ resistant Pseudoalteromonas sp. possess capability to adsorb toxic TBTCl in marine environments (Mimura et al., 2008). Therefore alteration in cell morphology due to TBTCl exposure may be a protective mechanism adapted by the TBTCl resistant Pseudomonas stutzeri strain DN2.

\section{Biotransformation of TBTCl}

The quantity of purified biotransformed product of TBTCl obtained after subsequent purification steps was $237 \pm 0.85 \mathrm{mg} / \mathrm{L}$.

\section{FTIR and UV-Vis Spectrophotometric analysis}

The FTIR spectrum of the purified biotransformation product of TBTCl clearly revealed presence of butyl group giving characteristic bands at 2958.80, 2926.01, 2872.01 and $2856.58 \mathrm{~cm}^{-1}$ (Supplementary figure 2). Prominent peak around $1450 \mathrm{~cm}^{-1}$ is due to $\mathrm{C}-\mathrm{H}$ bending vibrations of butyl group. A doublet at 705.95 and $669.30 \mathrm{~cm}^{-1}$ is also characteristic of $\mathrm{DBTCl}_{2}$ moiety. The comparison of the FTIR spectrum of the biotransformation product with standard TBTCl and DBTCl $_{2}$ (SIGMA-ALDRICH, USA) with Pubchem substance ID 24900253 and 24852336 respectively clearly demonstrated that the biotransformation product is different from pure $\mathrm{TBTCl}$ and matched with standard $\mathrm{DBTCl}_{2}$. Biotransformation product was also further confirmed by spectrophotometric analysis which showed a characteristic peak at $236 \mathrm{~nm}$ corresponding to $\mathrm{DBTCl}_{2}$.

\section{NMR analysis}

${ }^{1} \mathrm{H}$ NMR spectra of the control product showed characteristic peaks at 1.582, 1.313, 1.265 and $0.910 \mathrm{~cm}^{-1}$, whereas ${ }^{1} \mathrm{H}$ NMR spectra of purified biotransformation product gave peaks at $0.960,1.392,1.463$ and $1.800 \mathrm{~cm}^{-1}$ 


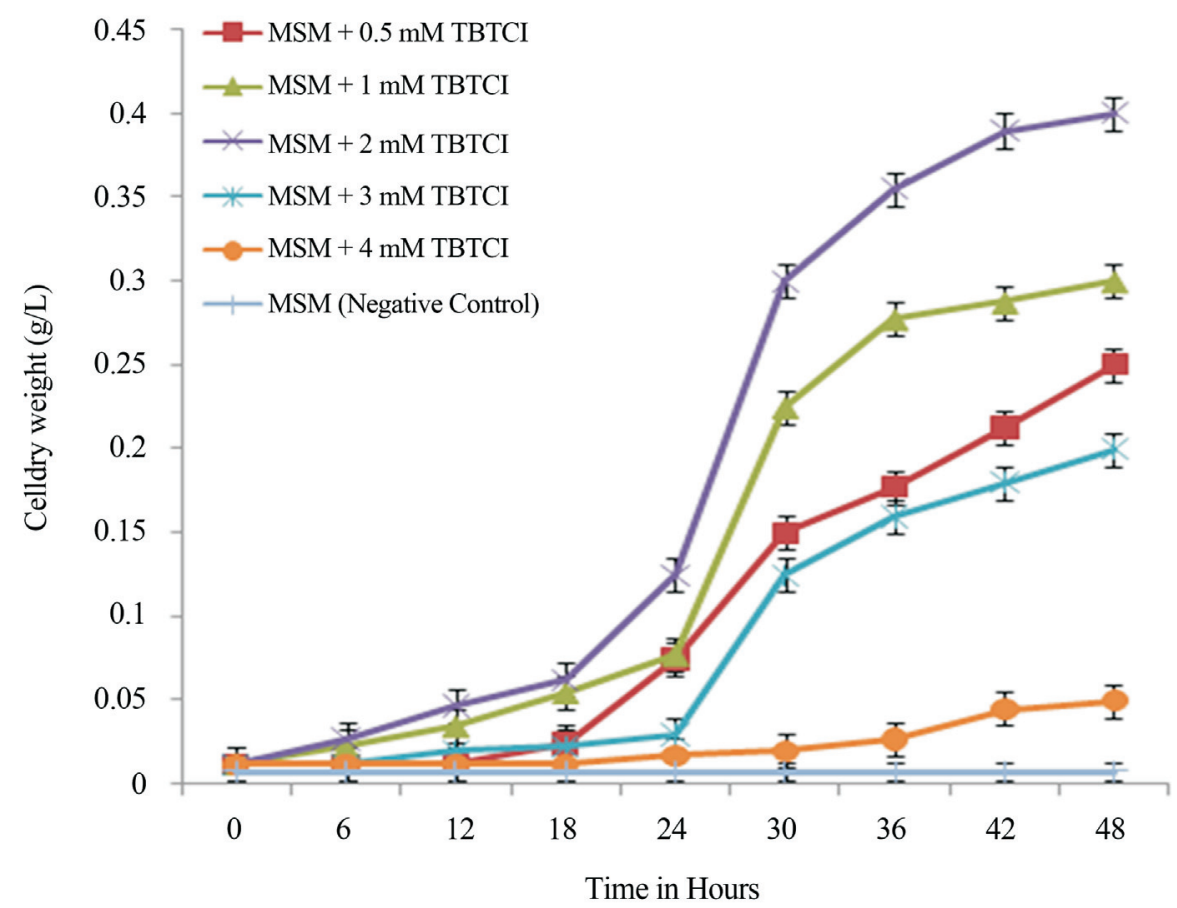

Figure 2 - Growth behaviour of Pseudomonas stutzeri strain DN2 in MSM amended with different concentrations of tributyltin chloride as a sole carbon source in terms of Cell dry weight $(\mathrm{g} / \mathrm{L})$ Vs Time in hours. Bacteria inoculated in plain MSM without TBTCl is considered as negative control.

(Figure 3. A, B). ${ }^{1} \mathrm{H}$ NMR spectral data of control and purified transformation products (Figure 3. A, B) were compared against standard ${ }^{1} \mathrm{H}$ NMR of TBTCl and $\mathrm{DBTCl}_{2}$ respectively, in the NMR Spectral database for organic compounds (SDBS). Purified biotransformation product significantly matched with standard $\mathrm{DBTCl}_{2}\left(\mathrm{SDBS}-{ }^{1} \mathrm{H}\right.$ NMR No. 3555HSP-00-035) which clearly confirmed it to be $\mathrm{DBTCl}_{2}$. The ${ }^{1} \mathrm{H} \mathrm{NMR}$ of control used in our experiment also matched with standard TBTCl (SDBS- ${ }^{1} \mathrm{H}$ NMR No. 6438 HSP-01-479). Small singlet peak at $7.26 \mathrm{~cm}^{-1}$ is due to solvent $\mathrm{CDCl}_{3}$ (Figure 3. B). Peak at $1.800 \mathrm{~cm}^{-1}$ specifically corresponds to the biotransformation product, $\mathrm{DBTCl}_{2}$ whereas peak at 1.582 corresponds to TBTCl. ${ }^{1} \mathrm{H}$ NMR spectrum of purified product showed slight differences in chemical shift (ppm) of protons from standard TBTCl which further confirmed TBTCl transformation product as

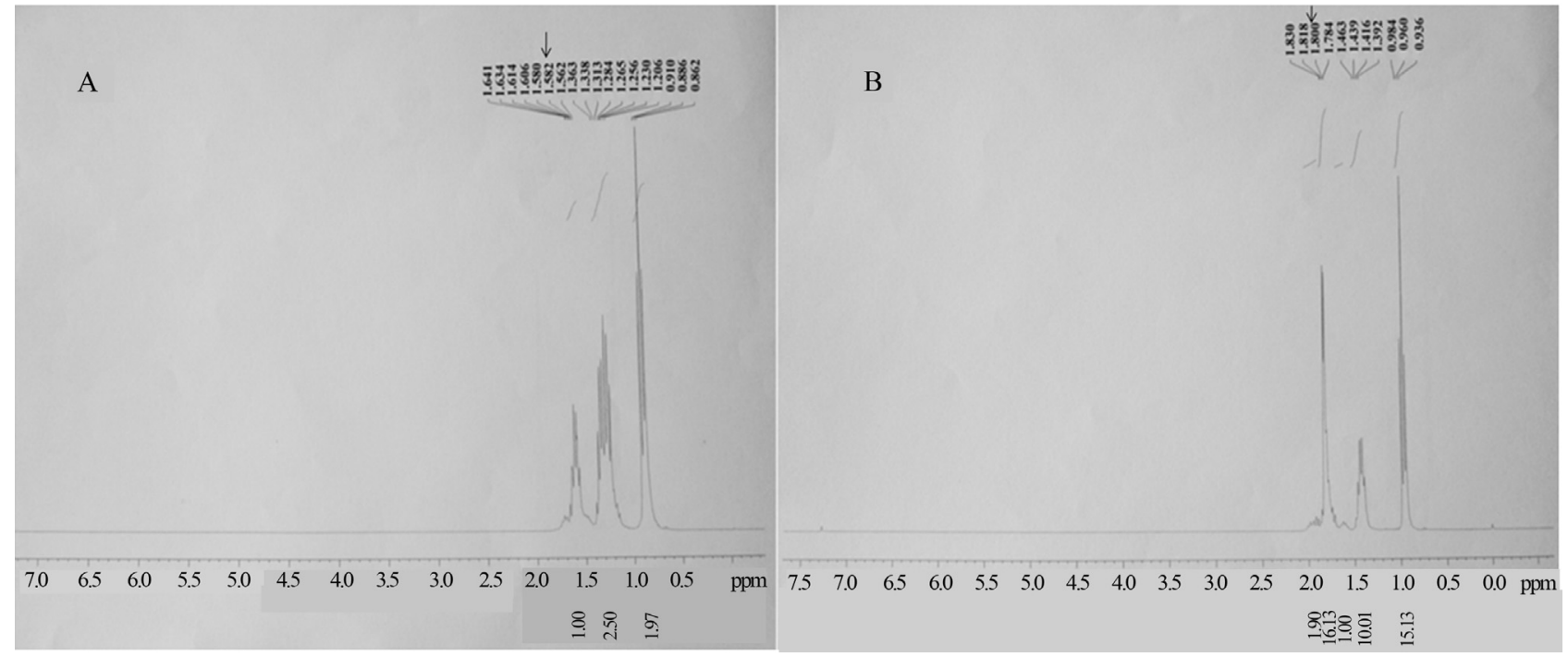

Figure 3 - ${ }^{1} \mathrm{HNMR}$ spectrum of (A) Control (Purified product from the sample devoid of bacterial cells) (B) Purified transformation product obtained af-

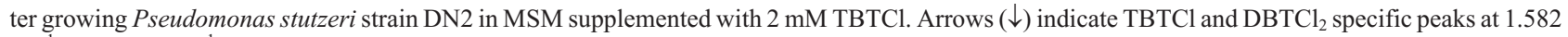
$\mathrm{cm}^{-1}$ and $1.800 \mathrm{~cm}^{-1}$ respectively. 
$\mathrm{DBTCl}_{2}$ (Figure 3. A, B). These studies have clearly demonstrated the biotransformation of TBTCl into less toxic product $\mathrm{DBTCl}_{2}$ by Pseudomonas stutzeri strain DN2 isolated from coastal sediments of Goa, India.

Biotransformation of TBTCl by bacteria has been reported to be through successive debutylation reactions from $\mathrm{TBTCl} \rightarrow \mathrm{DBTCl}_{2} \rightarrow \mathrm{MBTCl}_{3} \rightarrow$ inorganic tin via $\beta$ hydroxylation involving dioxygenases (Dowson et al., 1996). There are very few reports on TBTCl degradation by estuarine bacteria (Kawai et al., 1998; Mendo et al., 2003; Suehiro et al., 2006; Shamim et al., 2012), but detailed studies on biotransformation of TBTCl to less toxic compounds by bacteria isolated from TBTCl contaminated estuarine sediments have not been conducted so far. Several reports are available on TBTCl resistant bacteria but very little is known about resistance mechanisms adapted by these bacteria to overcome TBTCl stress and toxicity along with biotransformation mechanisms (Barug, 1981; Fukagawa et al., 1994; Jude et al., 2004; Ramachandran and Dubey, 2009; Fukushima et al., 2012; Sampath et al., 2012; Shamim et al., 2012). In the present communication we have clearly demonstrated TBTCl biotransformation potential of Pseudomonas stutzeri strain DN2 into its less toxic derivative $\mathrm{DBTCl}_{2}$ through successive debutylation which was further confirmed by NMR, FTIR and UV-Vis spectroscopic analysis of biotransformation product. It is interesting to note that Pseudomonas stutzeri strain DN2 can transform TBTCl into its less toxic derivative, $\mathrm{DBTCl}_{2}$ whereas it has been reported earlier to resist TBTCl through efflux mechanism (Jude et al., 2004). It is evident from our studies that Pseudomonas stutzeri strain DN2 tolerates high concentrations of TBTCl since it degrades it into less toxic $\mathrm{DBTCl}_{2}$ and also confirms that TBTCl degradation may serve as an additional resistance mechanism besides efflux based resistance mechanism in Pseudomonas stutzeri.

This study has evidently demonstrated that Pseudomonas stutzeri strain DN2 possesses other TBTCl resistance mechanisms along with biotransformation of TBTCl into $\mathrm{DBTCl}_{2}$. These mechanisms include metabolic utilization of TBTCl as a sole carbon source and significant morphological alterations as cell elongation and shrinkage. These studies have clearly suggested that this sediment bacterial strain may be employed as a potential microorganism to clean up TBTCl contaminated environmental sites.

Pseudomonas stutzeri strain DN2 possessing significant potential to biotransform TBTCl to less toxic $\mathrm{DBTCl}_{2}$ and utilizing it as sole carbon source proves to be an important microorganism which could be used to further characterise TBTCl resistance mechanisms at molecular level. We are trying to explore molecular mechanisms of TBTCl biotransformation operational in this bacterial strain. Our studies on Pseudomonas stutzeri strain DN2 have clearly demonstrated that this strain can be employed for environmental cleanup of TBTCl contaminated estuarine sites.

\section{Acknowledgement}

Prof. S. K. Dubey is thankful to Department of Biotechnology, Govt. of India for financial support as a major $\mathrm{R} \& \mathrm{D}$ grant. The authors are also thankful to Dr. M. S. Prasad and Mr. Vijay Khedekar from National Institute of Oceanography, Goa, India for scanning electron microscopy and Dr. Rohan Kunkalekar from Chemistry department Goa University for FTIR analysis and Dr. Lisette De Souza from National Institute of Oceanography, Goa, India for NMR analysis.

\section{References}

Ayanda OA, Fatoki OS, Adekola FA, Ximba BJ (2012) Fate and Remediation of Organotin Compounds in Seawaters and Soils. Chem Sci Trans 1:470-481.

Barug D (1981) Microbial degradation of bis(tributyltin) oxide. Chemosphere 10:1145-1154.

Bryan GW, Gibbs PE, Burt RG (1988) Comparison of the effectiveness of tri-n-butyltin chloride and five other organotin compounds in promoting the development of imposex in dog-whelk Nucella lapillus. J Mar Biolog Assoc UK 68:733-744.

Clark EA, Sterritt RM, Lester JN (1988) The fate of tributyltin in aquatic environment. Environ Sci Technol 22:600-604.

Cruz A, Caetano T, Suzuki S, Mendo S (2007) Aeromonas veronii, a tributyltin (TBT) degrading bacterium isolated from an estuarine environment, Ria de Aveiro in Portugal. Mar Environ Res 64:639-650.

Cruz A, Henreques I, Correia A, Suzuki S, Mendo S (2010) Aeromonas molluscorum Av27: A potential natural tool for TBT decontamination. Interdidciplinary studies on environmental chemistry- Biological response to contaminants 37 46.

Devi P, Wahidullah S, Rodrigues C, D. Souza L (2010) The Sponge-associated Bacterium Bacillus licheniformis SAB1: A Source of Antimicrobial Compounds. Mar. Drugs 8:1203 -1212 .

Dowson PH, Bubb JM, Lester JN (1996) Persistence and degradation pathways of tributyltin in freshwater and estuarine sediments. Estuar Coast Shelf Sci 42:551-562.

Dubey SK, Roy U (2003) Biodegradation of tributyltins (organotins) by marine bacteria. Appl Organomet Chem 17:3-8.

Dubey SK, Tokashiki T, Suzuki S (2006) Microarray mediated transcriptome analysis of the TBT resistant Pseudomonas aeroginosa $25 \mathrm{~W}$ in the presence of TBT. J Microbiol 44:200-205.

Fukagawa T, Konno S, Takama K, Suzuki S (1994) Occurrence of tributyltin and methyl mercury tolerant bacteria in natural sea water to which TBT was added. J Mar Biotechnol 1:211-214.

Fukushima K, Dubey SK, Suzuki S (2009) Quantitative analysis of expression of TBT regulated genes in TBT resistant Pseudomonas aeroginosa $25 \mathrm{~W}$. Interdisciplinary studies on environmental chemistry - environmental research in Asia 163-166.

Fukushima K, Dubey SK, Suzuki S (2012) YgiW homologous gene from Pseudomonas aeruginosa $25 \mathrm{~W}$ is responsible for tributyltin resistance. J Gen Appl Microbiol 58:283-289. 
Gadd GM (2000) Microbial interaction with TBT compounds, detoxification and environmental fate. Sci Total Environ 258:119-127.

Garg A, Meena RM, Bhosle NB (2010) Distribution of butyltins in waters and sediments of the Mandovi and Zuari estuaries, west coast of India. Environ Monit Assess 165:643-651.

Horiguchi T (2006) Masculinization of female gastropod molluscs induced by organotin compounds, focussing on mechanism of action of tributyltin and triphenyltin for development of imposex. Environ Sci 13:77-87.

Jadhav S, Bhosle NB, Massanisso P, Morabito R (2009) Organotins in the sediments of the Zuari estuary, west coast of India. Environ Manage 9:4-7.

Jude F, Arpin C, Castang C, Capdepuy M, Caumette P, Quentin C (2004) TbtABM, a multidrug efflux pump associated with tributyltin resistance in Pseudomonas stutzeri. FEMS Microbiol Lett 232:7-14.

Kawai S, Kurokawa Y, Harino H, Fukushima M (1998) Degradation of tributyltin by a bacterial strain isolated from polluted river water. Environ Pollut 102:259-263.

Krieg NR, Holt JG (1984) Bergey's manual of systemic bacteriology, vol 1. The Williams and Wilkins, Baltimore, USA 140-309.

Krishnamurthy R, Cabral L, Vidya R, Dubey SK (2007) Isolation and biological characterization of a TBTCl degrading marine bacterium, Vibrio sp. From Bombay High Oil Field, India. Curr Sci 93:1073-1074.

Lee SE, Chung JW, Won HS, Lee DC, Lee YW (2012) Removal of methylmercury and tributyltin (TBT) using marine microorganisms. Bull Environ Contam Toxicol 88:239-244

Lemos MFL, Esteves AC, Pestana JLT (2011) Fungicides as Endocrine Disrupters in Non-Target Organisms, Fungicides Beneficial and Harmful Aspects, InTech, Rijeka, Croatia. $179-196$.

Mendo SA, Nogueira PR, Ferreira SCN, Silva RG (2003) Tributyltin and triphenyltin toxicity on benthic estuarine bacteria. Fresenius Environ Bull 12:1361-1367.

Mimura H, Sato R, Sasaki Y, Furuyama Y, Taniike A, Yoshida K, Kitamura A (2008) Accelerator analysis of tributyltin ad- sorbed onto the surface of a tributyltin resistant marine Pseudoalteromonas sp. Cell Int J Mol Sci 9:1989-2002.

Naik MM, Dubey SK (2011) Lead - enhanced siderophore production and alteration in cell morphology in Pseudomonas aeruginosa strain 4 EA. Curr Microbiol 62:409-414.

Pain A, Cooney JJ (1998) Characterization of organotin-resistant bacteria from Boston Harbor sediments. Arch Environ Contam Toxicol 35:416-421.

Ramachandran V, Dubey SK (2009) Expression of TBTClinduced periplasmic proteins in a tributyltin chloride resistant marine sediment bacterium Alcaligenes sp. Curr Sci 97:1717-1718.

Sampath R, Venkatakrishnan H, Ravichandran V, Chaudhury RR (2012) Biochemistry of TBT-degrading marine Pseudomonads isolated from Indian coastal waters .Water Air Soil Pollut 223:99-106.

Sasser M (1990) Identification of bacteria through fatty acid analysis. Methods in Phytobacteriology. Akademiai Kiado, Budapest, pp 199-204.

Shamim K, Naik MM, Pandey A, Dubey SK (2012) Isolation and identification of Aeromonas caviae strain KS-1 as TBTC and Lead resistant estuarine bacteria. Environ Monit Assess 185:5243-5249.

Sousa ACA, Barroso CM, Tanabe S, Horiguchi T (2010) Involvement of Retinoid X Receptor in Imposex Development in Nucella lapillus and Nassarius reticulates - Preliminary Results. Interdisciplinary Studies on Environmental Chemistry - Biological Responses to Contaminants, Terrapub, pp 189-196.

Spectral database for organic compounds SDBS. Available at: http://sdbs.riodb.aist.go.jp/sdbs/cgi-bin/direct_frame_top.cgi

Suehiro F, Kobayashi T, Nonaka L, Tuyen BC, Suzuki S (2006) Degradation of Tributyltin in microcosm using Mekong river sediment. Microb Ecol 52:19-25.

Wuertz S, Miller CE, Pfister RM, Cooney JJ (1991) Tributyltin-Resistant bacteria from estuarine and fresh water sediments. Appl Environ Microbiol 57:2783-2789.

All the content of the journal, except where otherwise noted, is licensed under a Creative Commons License CC BY-NC. 


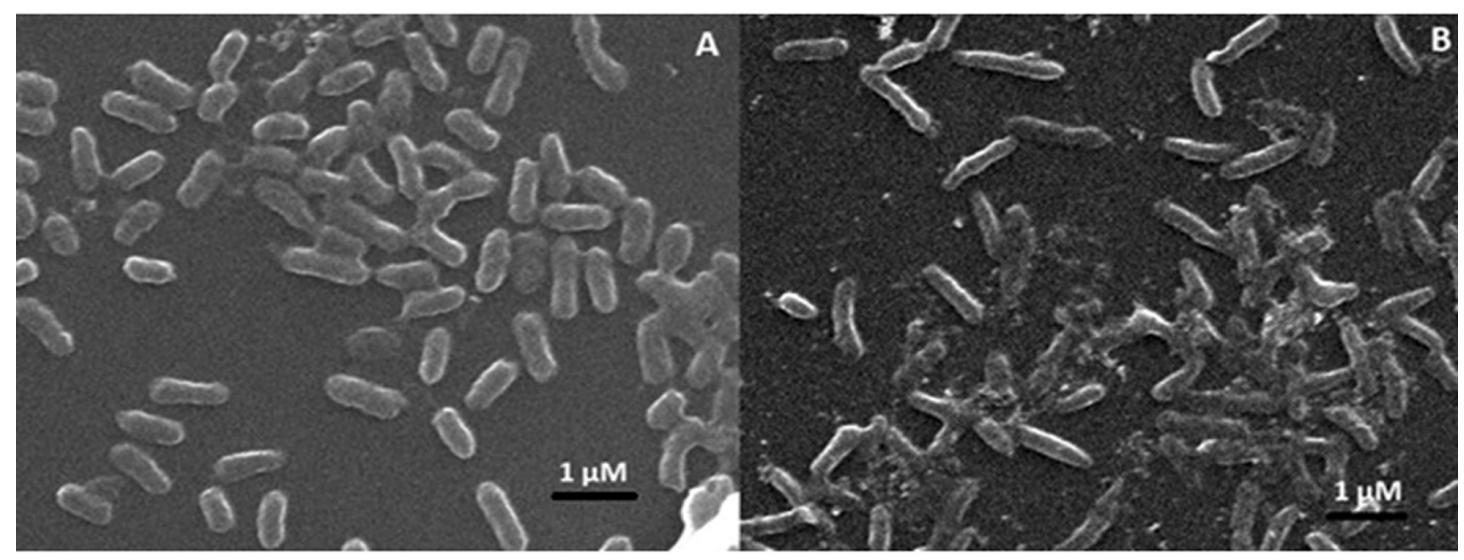

Figure S1 - Scanning electron microscopic analysis of Pseudomonas stutzeri strain DN2 (A) Grown in MSM with 0.1\% glucose as sole carbon source without TBTCl; (B) Grown in MSM with $2 \mathrm{mM}$ TBTCl as a sole carbon source (SEM magnification X 9,000). 


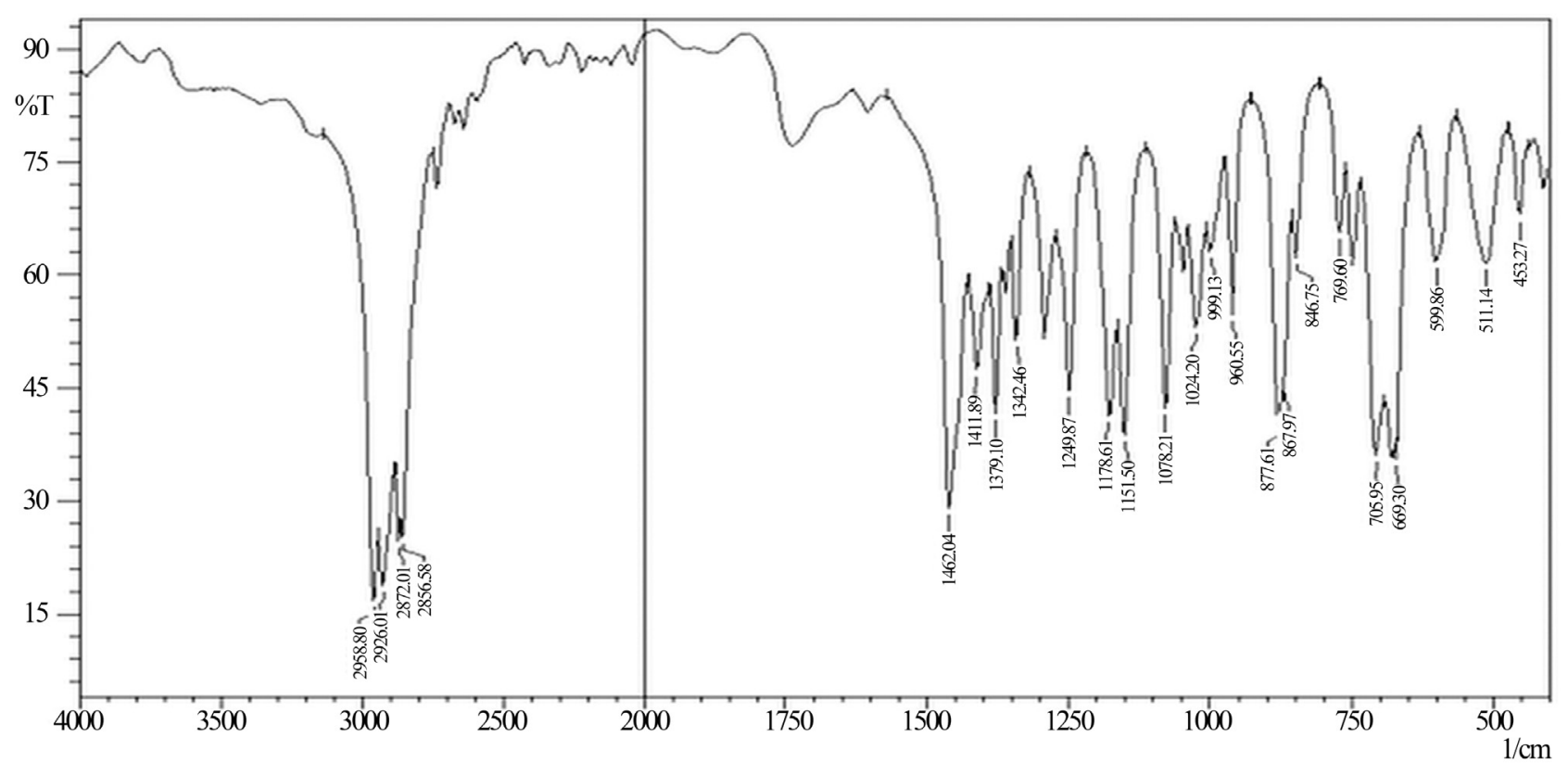

Figure S2 - FTIR spectrum of the purified transformation product obtained after growing Pseudomonas stutzeri strain DN2 in MSM supplemented with $2 \mathrm{mM} \mathrm{TBTCl}$ as a sole carbon source. 